Jurnal ASPIKOM, Vol. 7, No. 1, January 2022, pp. 142-157

P-ISSN: 2087-0442, E-ISSN: 2548-8309

DOI: http://dx.doi.org/10.24329/aspikom.v7i1.895

\title{
Aisyiyah Organizational Communication in Realizing the True Islamic Society
}

\author{
Adhianty Nurjanah*, Dyah Mutiarin, Gatot Supangkat, M. Iqbal \\ Universitas Muhammadiyah Yogyakarta, Jl. Brawijaya Tamantirto, Bantul, Indonesia \\ *Corresponding author, e-mail: adhianty@umy.ac.id
}

\begin{abstract}
Aisyiyah is a Muhammadiyah women's organization and has a mission to fight for a true Islamic society. This study aims to determine how organizational communication is carried out by the Aisyiyah Ngampilan Branch Manager (PCA) to create a true Islamic society in Ngampilan Village, Yogyakarta. The method used in this study is the mix-method to measure the effectiveness of organizational communication carried out. The results of the quantitative data test with Standard Deviation 1.96 show that downward communication is 2.213, up is 2.321, horizontal is 2.7801, and interline is 2.8011, which has a positive and significant effect on Organizational Communication in realizing true Muslims. PCA Ngampilan realizes true Islam through various social, educational, and religious activities, Business Charities, giving compensation. In addition, PCA Ngampilan prioritizes the persuasive communication of Hablumminannas, which prioritizes good relations and helping others, so that the Aisyiyah Organization is more readily accepted in the community.
\end{abstract}

Keywords: Aisyiyah; Communication organization; The true Islamic society

\begin{abstract}
Abstrak
Aisyiyah adalah organisasi wanita Muhammadiyah dan memiliki misi memperjuangkan masyarakat Islam yang sebenar-benarnya. Penelitian ini bertujuan untuk mengetahui bagaimana komunikasi organisasi yang dilakukan oleh Pimpinan Cabang Aisyiyah (PCA) Ngampilan untuk mewujudkan masyarakat Islam yang sebenar-benarnya di Kelurahan Ngampilan Yogyakarta. Metode yang digunakan pada penelitian ini yakni mix method, untuk mengukur tingkat efektifitas komunikasi organisasi yang dilakukan. Hasil uji data kuantitatif dengan Standart Deviation 1,96 menunjukkan bahwa komunikasi ke bawah sebesar 2.213, ke atas 2.321, horizontal 2.7801, dan interline 2.8011 yang memiliki arti berpengaruh positif dan signifikan terhadap Komunikasi Organisasi dalam mewujudkan umat Islam yang sebenarbenarnya. PCA Ngampilan mewujudkan Islam yang sebenar-benarnya melalui berbagai kegiatan sosial, pendidikan dan keagamaan, Amal Usaha TK/KB/TPA, Pemberian santunan, mengadakan senam sehat setiap 3 bulan sekali. Selain itu PCA Ngampilan mengutamakan komunikasi persuasif Hablumminannas, yang mengutamakan hubungan baik dan membantu orang lain, sehingga Organisasi Aisyiyah lebih mudah diterima di masyarakat.
\end{abstract}

Kata Kunci: Aisyiyah; Komunikasi organisasi; Islam sebenar-benarnya 


\section{Introduction}

Aisyiyah is the Muhammadiyah's women's organization which was founded on 27 Rajab 1335 H, coinciding on May 19, 1917 AD by KH Ahmad Dahlan, the founder of Muhammadiyah. Aisyiyah organization was chaired by Dahlan's wife, Nyai Walidah. Aisyiyah organization is characterized by mutual respect for logical and creative decisions from the agreement of organizational members (Nurdin, 2020). Critically re-read and re-interpret the Islamic sources and jurisprudence with a renewed ijtihad (independent reasoning) and ultimately seek to emancipate religion from popular interpretations of Islam (Badri, 2018). 'Aisyiyah operates in the religious social field and is not political. The organizational structure of 'Aisyiyah, among others, at the central level of the PPA (Central Executive' Aisyiyah), is located in Yogyakarta, PWA (Regional Leadership' Aisyiyah) scattered in several provinces of Indonesia, PDAs (Regional Leaders' Aisyiyah) at the city / Madya level, PCA (Leadership) Branch' Aisyiyah) at the Subdistrict level, PRA (Branch Manager' Aisyiyah) at the Subdistrict level.

Head of Aisyiyah Branch (PCA) Ngampilan Yogyakarta is the Head of Aisyiyah Branch at the District level. Administratively, Ngampilan Subdistrict is divided into two Kelurahans, namely Notoprajan and Ngampilan. Both are densely populated. Ngampilan Sub-Districts are diverse and diverse societies in terms of religion, social status, education, and even their life outlook / political views. The existence of compounding in the community in the District of Ngampilan, especially in the Village of Ngampilan, is a challenge for the Chief of Aisyiyah Branch (PCA) Ngampilan, especially in realizing the true Islamic society.

The village of Ngampilan is often dubbed the "abangan" area because many of its people have the Islam Abangan belief.

"There is the Islamic term Islam Santri and Islam Abangan. Islam Santri is a group of devout Muslims who embrace Islam and carry out the Shari'a seriously, carry out religious orders, and try to cleanse their faith from shirk behavior. In contrast, Islam Abangan is a group of Muslims whose way of life is still dominated by pre-Islamic Javanese traditions. The tradition emphasizes the integration of all elements of religion. Meanwhile, based on ritual participation, Islam Santri is more oriented towards carrying out rituals that are taught by Islam in a standard manner such as prayer, fasting, pilgrimage, reciting the AlQuran." (Siti Bariah, Aisyiyah Ngampilan Branch Manager, interview April 20, 2020).

Referring to this, PCA can approach the community through organizational communication. Organization as an open system for engagement and relationships between individuals and other components in line with common goals. In realizing a true Islamic society, the Chairperson of PCA Ngampilan requires persuasive organizational communication internally and externally. Goldhaber explains that organizational communication is the process of creating and transacting messages on an interdependent network to cope with a dynamic environment (Muhammad, 2017). According to Pace and Faules, communication in an organization or institution, both profit and non-profit, has four main functions: (1) Informative, (2) Regulation, (3) Persuasive, and (4) Integrative (R. W. Pace \& Faules, 2015).

This research is certainly born based on inspiration from previous research. Previous research revealed that religious communication could translate spiritual values 
because other people will believe with a religious approach through sermons (Rubtcova et al., 2017). Furthermore, Rosyid M. Harun (2015) explains that organizational communication is the main key in organizing because organizational communication is a mediator for organizational members to build loyalty between teachers and students in the Darussalam Gontor Islamic Boarding School Organization. However, the research conducted by Harun has not shown an effective form of organizational communication to realize the Islamic values included in organizational communication. The last reference was written by Krafess (2005) with a paper entitled The Influence of Muslim Religion in Humanitarian Aid. This article explains that Islamic approaches such as zakat, waqf, kafffara are one significant way to support assistance for fellow Muslims. They had the meaning of running Islam only with HabluminaAllah.

Based on some research above, this research will fill the gap and give novelty to enrich the treasures of organizational communication with a religious approach by complementing previous research, which includes the Islamic context. This research would become a supporter and bring important value for organizational communication, and has an impact on changing society to realize true Islam. Organizations play a role in implicitly conveying Islamic values, in contrast to previous research, which views religious communication only in da'wah and the importance of organizational communication with habluminannas (relationships with fellow human) to carry out the values taught by true Islam. Based on the background explanation above and previous research, this study aims to determine how organizational up, down, horizontal, and interline communication is carried out by the Chairperson of the Aisyiyah Branch (PCA) Ngampilan to create a true Islamic society in Ngampilan District Yogyakarta.

\section{Method}

The type of research in this research is the field research where the researchers use mixed/combination research (mixed methodology). Mixed methods produce more comprehensive facts in analyzing research problems because this research can use all data collection tools according to the type of data needed. Mixed methods is a research approach that combines qualitative research with quantitative research (Creswell, 2010). Meanwhile, according to Sugiyono mix methods are research methods by combining two research methods at once, qualitative and quantitative, in research activity, so that more comprehensive, valid, reliable, and objective data will be obtained (Sugiyono, 2011). In the study of Aisyiyah Organizational Communication in Realizing the True Islamic Society (Case Study of Aisiyah Ngampil Yogyakarta PCA), the researchers used mixed methods with the approach presented by Sugiyono because the implementation of research using the two methods was carried out simultaneously.

The primary data was collected using questionnaires and in-depth interviews with relevant stakeholders chosen purposively to meet research needs. Meanwhile, the secondary data is collected using literature and documentation to confirm and strengthen the data for analysis. The survey results are then processed using the SmartPLS 3.0 software. The survey conducted in this research refers to the framework of research and hypotheses. The research framework is displayed in Figure 1. 


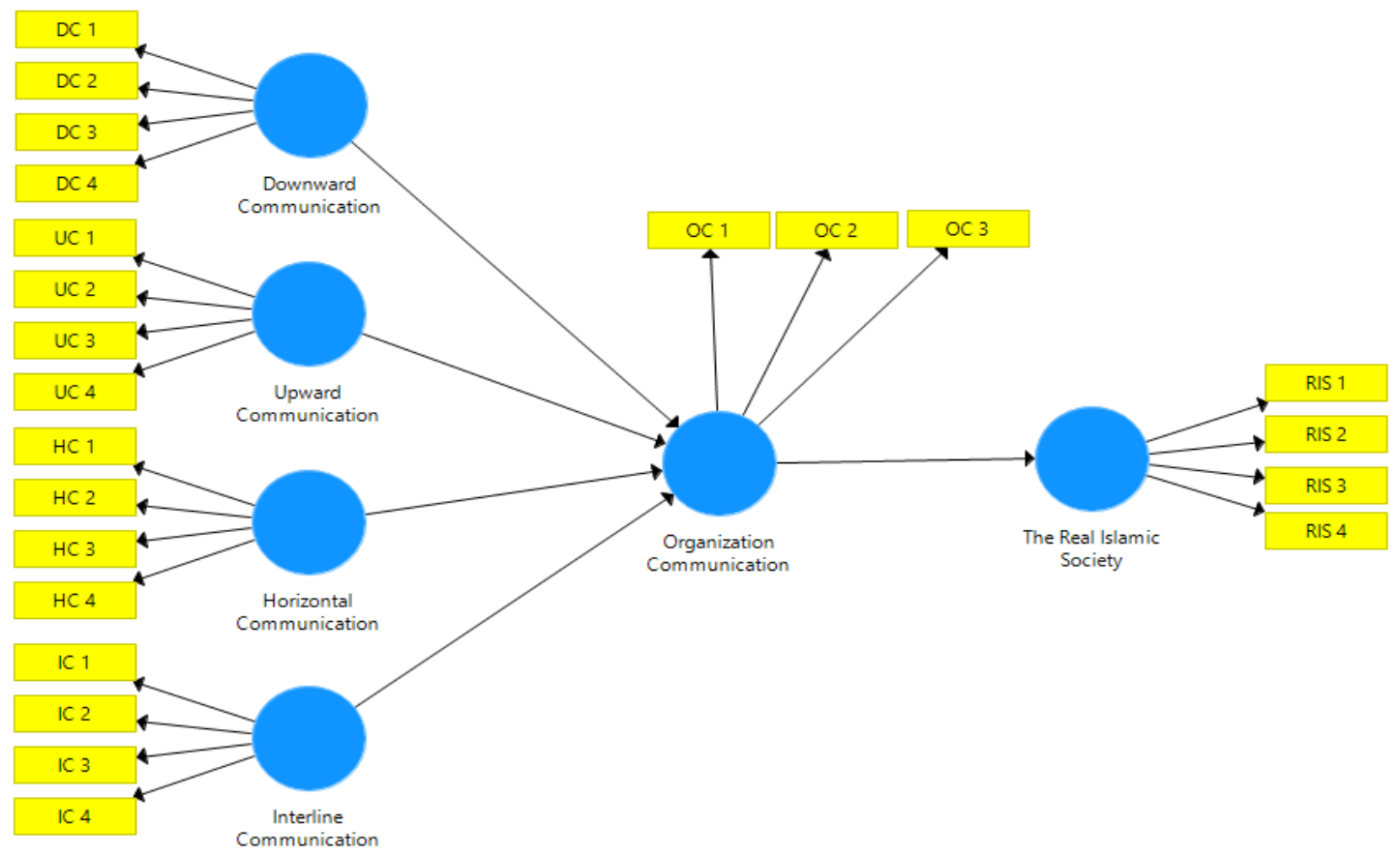

Figure 1. Research Framework

Based on Figure 1, it can be concluded that the hypothesis in this research is as follows: H1: Downward Communication has a significant effect on Organizational Communication

$\mathrm{H} 2$ : Upward Communication has a significant effect on Organizational Communication H3: Horizontal Communication has a significant effect on Organizational Communication

H4: Interline Communication has a significant effect on Organizational Communication H5: Organizational Communication has a significant influence on the formation of the true Islamic community

\section{Results and Discussion}

Organizational Communication of Aisyiyah Ngampilan Branch Chief in Realizing the True Islamic Society

Aisyiyah's organization carries out its mission to actualize Islam, implemented through an organizational communication approach, namely applying internal and external communication. Internal Communication of PCA Ngampilan intended to build the inner spirit of the organization in realizing the true Islam through an approach that will be moved to the outside community. According to the Chairperson of the PCA Ngampilan, effective internal communication can be applied by having two-way communication and good quality communication in the internal organization. There is the same concept of Markgraf that a good internal communication company has twoway communication, ability inter-personal, awareness and culture of risk, clarity of messages/information, frequency messages/information, periodic learning, risk management governance, structure internal communication, management knowledge and leadership strength (Markgraf, 2003). Then, External Communication on PCA Ngampilan is also one of the important things to pay attention to, according to PCA Ngampilan. This is because the PCA's goal in Ngampilan is to realize that the Ngampilan community is still minimal in understanding Islam as a whole, so the 
Ngampilan PCA created a program with the spirit to make the Ngampilan community easy to adapt and accept the true values of Islam. The results of the research can be explained as follows:

\section{Test the Outer Model}

Outer model testing evaluates the outer model with its reflection indicator. Three criteria are indicators of reflection, namely loading factor, composite reliability, and Average Variance Extracted (AVE). The following is the output of the outer research model explained in Table 1.

The first criterion is the Validity Test which can be seen from the results of the outer model score, the AVE value. The validity of data that can be seen from AVE has a limit value for data that can be said to be valid. The AVE value is valid if the AVE score is more than 0.50. If the AVE score is less than 0.05, the data is not considered valid. The validity of the data seen from the loading factor also has a value limit for data duped as valid. The loading factor value is said to be valid if the score from the crossloading is more than 0.70 . If the score of the loading factor is less than 0.70 , then the data cannot be said to be valid.

Table 1. Outer Research Model

\begin{tabular}{|c|c|c|c|c|}
\hline Construct & Item & $\begin{array}{l}\text { Loading } \\
\text { Factor }\end{array}$ & $\begin{array}{l}\text { Composite } \\
\text { Reliability }\end{array}$ & $\begin{array}{l}\text { Average Variance } \\
\text { Extracted (AVE) }\end{array}$ \\
\hline \multirow[t]{4}{*}{ Downward Communication } & DC 1 & 0.880 & 0.924 & 0.753 \\
\hline & DC 2 & 0.842 & & \\
\hline & DC 3 & 0.870 & & \\
\hline & DC 4 & 0.878 & & \\
\hline \multirow[t]{4}{*}{ UpwardCommunication } & UC 1 & 0.766 & 0.888 & 0.665 \\
\hline & UC 2 & 0.823 & & \\
\hline & UC 3 & 0.836 & & \\
\hline & UC 4 & 0.836 & & \\
\hline \multirow[t]{4}{*}{ HorizontalCommunication } & HC 1 & 0.898 & 0.947 & 0.818 \\
\hline & $\mathrm{HC} 2$ & 0.921 & & \\
\hline & HC 3 & 0.890 & & \\
\hline & HC 4 & 0.908 & & \\
\hline \multirow[t]{4}{*}{ Interline Communication } & IC 1 & 0.911 & 0.943 & 0.806 \\
\hline & IC 2 & 0.867 & & \\
\hline & IC 3 & 0.893 & & \\
\hline & IC 4 & 0.919 & & \\
\hline \multirow[t]{3}{*}{ Organizational Communication } & OS 1 & 0.904 & 0.929 & 0.813 \\
\hline & OS 2 & 0.900 & & \\
\hline & OS 3 & 0.901 & & \\
\hline \multirow[t]{4}{*}{ The Real Islamic Society } & RIS 1 & 0.885 & 0.933 & 0.778 \\
\hline & RIS 2 & 0.849 & & \\
\hline & RIS 3 & 0.886 & & \\
\hline & RIS 4 & 0.906 & & \\
\hline
\end{tabular}

The validity test results in Table 1 show that all research indicators in each research variable consisting of Downward Communication, Upward Communication, Horizontal Communication, Interline Communication, Organizational Communication, The True Islamic Society have a factor value of greater than 0.700 . Also, all research variables have AVE values greater than 0.500. Thus, it can be concluded that all indicators in all research variables are declared valid or have met the convergent 
validity. The table show communication satisfaction in the Aisyiyah Organization Ngampilan Branch in Realizing the True Islamic Society. According to Down \& Hazen in Yantara (2015), these aspects are included in the Communication climate dimension. Namely, organizational communication enters into motivating stimulation to meet organizational goals. This dimension leads to a healthy and quality organizational communication system (Down \& Hazen, in Yantara, 2015).

In addition to the validity test, a reliability test is also measured by the criteria, namely the composite reliability of the indicator block that measures the construct. The construct is declared reliable if the composite reliability and Cronbach's alpha values are above 0.70 (Ghozali, 2006). Output composite reliability and Cronbach's alpha can be seen in Table 1. Based on these data, the value or output composite reliability in Table 1 shows that the value of each construct is above 0.70 . So, it can be concluded that each construct in the estimated model has good reliability. The result of reliability shows that the test context for each variable has an appropriate level of reliability, and the use of organizational communication context to test the level of effectiveness in Ngampilan PCA organizational activities has been appropriate, especially in testing Downward Communication, Upward Communication, Horizontal Communication, Interline Communication, and Organizational Communication.

\section{Inner Model Test}

Testing the inner or structural model is done to see the relationship between the construct, the significance value, and the research model's R-square. The structural model is evaluated using R-square for the dependent construct of the test and the significance of the coefficient of structural path parameters. In assessing a model with Smart PLS 3.0, it starts by looking at the R-square for each latent dependent variable. Table 2 is the result of the R-square estimation using Smart PLS 3.0.

Table 2. R-Square results

\begin{tabular}{lc}
\hline \multicolumn{1}{c}{ Variabel } & R-Square \\
\hline Organization Communication & 0.770 \\
The Real Islamic Society & 0.671 \\
\hline
\end{tabular}

Table 2 shows the R-square value in the research construct. The value of $\mathrm{R}$ Square on Organizational Communication Variable is 0.7 70. It means that the effect of Downward Communication, Upward Communication, Horizontal Communication, Interline Communication Variable on Organizational Communication Variable is $77 \%$. In addition, the R-square value of the True Islamic Community Variable is 0.671. It means that the Organizational Communication variable on The True Islamic Society variable is $67.1 \%$.

If associated with the Rule of Thumb for testing R Square, according to (Ghozali, 2006), the structural model which has an R-square (R2) of 0.67 indicates that the model is "good", R-square (R2) of 0.33 indicates that the model is "moderate", and R-square (R2) of 0.19 indicates that the model is "weak". Therefore, it can be concluded that in this study, the variables that affect the Organizational Communication variable have a good or high level of influence because it has a $77 \%$ dose level variable for the organizational communication model and a good value for referring to Islam which is $67.1 \%$. From the results of this data, it can be seen that organizational communication with several approaches up, down, and between lines has a good influence on organizational communication effectiveness. Because communication is the organization's core, there will be no organizational activity without communication. So 
this is in line with the results of the data obtained that communication plays a role and affects the value of the true Islamic community variable (Hermana et al., 2004).

\section{Hypothesis Test}

Hypothesis testing between variables, namely exogenous variables to endogenous variables $(\gamma)$ and endogenous variables to exogenous variables $(\beta)$, is done with the bootstrap resampling method after knowing the validity and reliability of the data. The test statistic used is the $t$ statistic or the t-test. The comparative $t$ value in this research was obtained from the $t$ table. The test was declared significant if the T-statistic was $>$ 1.96 and the value of $\mathrm{P}$ values <0.05 (Haryono, 2017). Hypothesis testing is done by looking at the bootstrap resampling results' output path coefficient, as shown in Figure 2 and according to Table 3.



Figure 2. Research Both strapping Output

Table 3. Research Hypothesis Test

\begin{tabular}{ccccccc}
\hline & \multicolumn{6}{c}{ PCA NGAMPILAN } \\
\cline { 2 - 7 } Variables & $\begin{array}{c}\text { Original } \\
\text { Sample } \\
(\mathrm{O})\end{array}$ & $\begin{array}{c}\text { Sample } \\
\text { Mean } \\
(\mathrm{M})\end{array}$ & $\begin{array}{c}\text { Standard } \\
\text { Deviation } \\
(\text { STDEV })\end{array}$ & $\begin{array}{c}\text { T Statistics } \\
(\mid \mathrm{O} / \text { STDEV })\end{array}$ & $\begin{array}{c}\mathrm{P} \\
\text { Values }\end{array}$ & $\begin{array}{c}\text { Assessments } \\
\text { from } \\
\text { Hypothesis }\end{array}$ \\
\hline DC ->OC & 0.276 & 0.276 & 0.125 & 2.213 & 0.027 & Approved \\
\hline UC ->OC & 0.300 & 0.306 & 0.129 & 2.321 & 0.021 & Approved \\
\hline HC $>$ OC & 0.321 & 0.316 & 0.119 & 2.701 & 0.007 & Approved \\
\hline 1C $->$ OC & 0.311 & 0.375 & 0.118 & 2.811 & 0.013 & Approved \\
\hline OC $>$ RIS & 0.814 & 0.813 & 0.054 & 15.062 & 0.000 & Approved \\
\hline
\end{tabular}

\section{Hypothesis Test 1}

The first hypothesis test in this research is:

Ha: Downward Communication has a significant effect on Organizational Communication

H0: Downward Communication does not have a significant effect on Organizational Communication. The explanation is according to Table 4 . 
Table 4. Hypothesis 1: Downward Communication -> Organizational Communication

\begin{tabular}{lcccccc}
\hline & $\begin{array}{c}\text { Original } \\
\text { Sample } \\
(\mathrm{O})\end{array}$ & $\begin{array}{c}\text { Sample } \\
\text { Mean } \\
(\mathrm{M})\end{array}$ & $\begin{array}{c}\text { Standard } \\
\text { Deviation } \\
(\text { STDEV) }\end{array}$ & $\begin{array}{c}\mathrm{T} \\
\text { Statistics }\end{array}$ & $\begin{array}{c}\mathrm{P} \\
\text { Values }\end{array}$ & $\begin{array}{c}\text { Hypothesis } \\
\text { Result }\end{array}$ \\
\hline $\mathrm{DC}->\mathrm{OC}$ & 0.276 & 0.276 & 0.125 & 2.213 & 0.027 & Approve \\
\hline
\end{tabular}

Table 4 shows that the statistical findings of hypothesis 1 have a $\mathrm{T}$ statistic value of 2,213. This figure shows that the hypothesis $\mathrm{T}$ statistic 1 exceeded the $\mathrm{T}$ statistic standard value of 1.96. In addition, the value of $P$ Values hypothesis 1 is equal to 0.027 , where $\mathrm{P}$ Values hypothesis 1 is smaller than 0.05. This means that Downward Communication has a positive and significant influence on Organizational Communication to realize the true Islamic community. The first hypothesis is accepted or proven (Ha is approved and H0 is rejected). De Vito (2011) has stated that downward communication will motivate in the name of productivity and the organization's achievement. There are several things conveyed in downward communication according to Katz and Kahn (Pace \& Faules, 2005; in Evelina \& Angeline, 2014), suggesting (1) information about how to do work, (2) information about the rationale for doing work, (3) information about policies and practices within the organization, (4) information about employee performance and (5) information to develop a sense of mission orders from a higher position level to a lower level to carry out operational tasks.)

\section{Hypothesis Test 2}

The second hypothesis test in this research is:

Ha: Upward Communication has a significant effect on Organizational Communication H0: Upward Communication does not have a significant effect on Organizational Communication. The explanation is presented according to Table 5.

Table 5. Hypothesis 2 Upward Communication -> Organizational Communication

\begin{tabular}{ccccccc}
\hline & $\begin{array}{c}\text { Original } \\
\text { Sample }(\mathrm{O})\end{array}$ & $\begin{array}{c}\text { Sample } \\
\text { Mean (M) }\end{array}$ & $\begin{array}{c}\text { Standard } \\
\text { Deviation } \\
\text { (STDEV) }\end{array}$ & $\begin{array}{c}\mathrm{T} \\
\text { Statistics }\end{array}$ & $\begin{array}{c}\mathrm{P} \\
\text { Values }\end{array}$ & $\begin{array}{c}\text { Hypothes } \\
\text { is Result }\end{array}$ \\
\hline $\begin{array}{c}\text { UC- } \\
>\text { OC }\end{array}$ & 0.300 & 0.306 & 0.129 & 2.321 & 0.021 & Approve \\
\hline
\end{tabular}

Table 5 shows that the statistical findings of hypothesis 2 have a $\mathrm{T}$ value of 2,321 statistics. This figure shows that the hypothesis $2 \mathrm{~T}$ statistic results exceed the $\mathrm{T}$ Statistic standard value of 1.96. In addition, the value of $P$ Values hypothesis 2 is equal to 0.021 in which the value of $\mathrm{P}$ Values hypothesis 2 is smaller than 0.05 . This means that Upward Communication has a positive and significant influence on Organizational Communication to realize the true Islamic community. The second hypothesis is accepted or proven (Ha is approved and $\mathrm{H} 0$ is rejected).

Upward communication is a variable that cannot be separated. All employees in the organization, except those in top positions, perhaps communicate upwards. This is also per what happened to the Aisyiyah Branch Manager that upward communication shows the true Islamic community. Previous research also carried out research related to upward communication, which assessed that communication from the bottom up positively influenced work motivation of subordinates to the Company (Markus, 2019). In this case, in PCA Ngampilan, organizational communication would provide a motivational boost to pass on values. According to Peterson \& Pace, the use of downward communication, which provides honest motivation and input and listens in 
upward communication, which in this case is done by members of the organization to the leadership, will make organizational communication effective (Jelahut, Karlinah, \& Novianti, 2021).

\section{Hypothesis Test 3}

The third hypothesis test in this research is:

Ha: Horizontal Communication has a significant effect on Organizational Communication

H0: Horizontal Communication does not have a significant effect on Organizational Communication. The explanation is presented according to Table 6.

Table 6. Hypothesis 3 Horizontal Communication -> Organizational Communication

\begin{tabular}{lcccccc}
\hline & $\begin{array}{c}\text { Original } \\
\text { Sample } \\
(\mathrm{O})\end{array}$ & $\begin{array}{c}\text { Sample } \\
\text { Mean } \\
(\mathrm{M})\end{array}$ & $\begin{array}{c}\text { Standard } \\
\text { Deviation } \\
(\text { STDEV) }\end{array}$ & $\begin{array}{c}\mathrm{T} \\
\text { Statistics }\end{array}$ & $\begin{array}{c}\mathrm{P} \\
\text { Values }\end{array}$ & $\begin{array}{c}\text { Hypothesis } \\
\text { Result }\end{array}$ \\
\hline HC->OC & 0.321 & 0.316 & 0.119 & 2.701 & 0.007 & Approve \\
\hline
\end{tabular}

Table 6 shows that the statistical findings of hypothesis 3 have a Statistical $\mathrm{T}$ value of 2.701. This figure shows that the hypothesis $3 \mathrm{~T}$ statistic results exceed the $\mathrm{T}$ Statistic standard value of 1.96. In addition, the P-value of Hypothesis 3 is 0.007 , where the P-value of Hypothesis 3 is smaller than 0.05. This means that Horizontal Communication has a positive and significant influence on Organizational Communication to realize the true Islamic community. The third hypothesis is accepted or proven ( $\mathrm{Ha}$ is accepted, and $\mathrm{H} 0$ is rejected). Horizontal communication is still influential in organizational communication. This is because communication between people can establish relationships and provide mutual motivation. According to Nathania (2014), horizontal communication is this communication flow. There is an exchange of information to the side, namely, showing that it is in accordance with the principles of function among the same people in an organization. Moreover, according to Swandhana, horizontal communication has a relationship with performance. As a managerial tool, communication is often expected to share information with members, coordinate activities, reduce the managerial burden and unnecessary rules, and improve performance (Swandhana, 2017).

\section{Hypothesis Test 4}

The fourth hypothesis test in this research is:

Ha: Interline Communication has a significant effect on Organizational Communication H0: Interline Communication does not have a significant effect on Organizational Communication. The explanation is shown in Table 7.

Table 7. Hypothesis 5 Interline Communication -> Organizational Communication

\begin{tabular}{lcccccc}
\hline & $\begin{array}{c}\text { Original } \\
\text { Sample } \\
(\mathrm{O})\end{array}$ & $\begin{array}{c}\text { Sample } \\
\text { Mean } \\
(\mathrm{M})\end{array}$ & $\begin{array}{c}\text { Standard } \\
\text { Deviation } \\
\text { (STDEV) }\end{array}$ & $\begin{array}{c}\mathrm{T} \\
\text { Statistics }\end{array}$ & $\begin{array}{c}\mathrm{P} \\
\text { Values }\end{array}$ & $\begin{array}{c}\text { Hypothesis } \\
\text { Result }\end{array}$ \\
\hline IC->OC & 0.311 & 0.375 & 0.118 & 2.811 & 0.013 & Approve \\
\hline
\end{tabular}

Table 7 shows that the statistical findings of hypothesis 4 have a statistical $\mathrm{T}$ value of 2,811. This figure shows that the $\mathrm{T}$ statistic hypothesis 4 results above the standard $\mathrm{T}$ statistic value of 1.96. In addition, the P-value for Hypothesis 4 is 0.013 , where the Pvalue of Hypothesis 4 is lower than 0.05 . This means that Interline Communication has 
a significant influence on Organizational Communication to realize the true Islamic community. The fourth hypothesis is accepted or proven (Ha is accepted, and H0 is rejected). Interline communication is defined as cross-channel communication (Information cross-communication across functional boundaries or work unit boundaries, between one another each other is not in the position of superior to subordinate) (Mahmudah, 2015).

Based on the results of the research above, it can be seen that organizational communication carried out by the Chairperson of Aisyiyah Branch (PCA) Ngampilan to realize the true Islamic community is to establish routine communication with external parties such as community organizations like PKK groups, RT social gathering groups, and Mother recitation groups in the Village in the Ngampilan Subdistrict.

\section{Hypothesis Test 5}

The fourth hypothesis test in this research is

Ha: Organizational Communication has a significant influence on the Real Islamic Society

H0: Organizational Communication does not significantly influence the Real Islamic Society. The explanation is shown in Table 8 .

Table 8. Hypothesis 5 Organizational Communication -> the Real Islamic Society

\begin{tabular}{lcccccc}
\hline & $\begin{array}{c}\text { Original } \\
\text { Sample } \\
(\mathrm{O})\end{array}$ & $\begin{array}{c}\text { Sample } \\
\text { Mean } \\
(\mathrm{M})\end{array}$ & $\begin{array}{c}\text { Standard } \\
\text { Deviation } \\
(\text { STDEV })\end{array}$ & $\begin{array}{c}\mathrm{T} \\
\text { Statistics }\end{array}$ & $\begin{array}{c}\mathrm{P} \\
\text { Values }\end{array}$ & $\begin{array}{c}\text { Hypothesis } \\
\text { Result }\end{array}$ \\
\hline OC->RIS & 0.814 & 0.813 & 0.054 & 15.062 & 0.000 & Approve \\
\hline
\end{tabular}

Table 8 shows that the statistical findings of hypothesis 5 have a $\mathrm{T}$ value of 15,062. This figure shows that the hypothesis $\mathrm{T}$ results exceed the $\mathrm{T}$ statistic standard value of 1.96. In addition, the P-Value of Hypothesis 5 is equal to 0.00 , where the $\mathrm{P}$ Values value of hypothesis 5 is smaller than 0 . 05. This means Organizational Communication has a positive and significant influence on the Real Islamic Society to realize the true Islamic society. The fifth hypothesis is accepted or opened (Ha accepted and $\mathrm{H} 0$ rejected). Through organizational communication, individuals can share and communicate a large number of actions and can create powerful and reliable social tools (Anshari et al., 2014). Based on the research results, the researchers finally get a picture of how the communication organization that carried out the Branch Aisyiyah Ngampilan In the Islamic Society was brought truthfully. The function of organizational communication carried out by the Branch Manager of Aisyiyah Ngampilan is information, coordination, and persuasion. This was stated in the interview of the Chairperson of the PCA Ngampilan below:

"The communication carried out by the PCA within the organization is between PCA members, and outside the PCA, namely in the community, the function is to share information related to policies from the Aisyiyah Central Executive, coordination related to PCA activities such as conducting recitations, meetings, etc. It is carried out through meetings and also through WAG. In realizing a truth, we cannot just frontally include Islamic values, Habluminnallah for example, reminding each other and always inviting the right prayer, and not doing activities that are not in accordance with the guidance of the Al-Qur'an AlHadith, however, in order for Aisyiyah to be accepted in the Ngampilan community, we use messages that are persuasive communication in nature, 
Hablumminannas, communication is inviting each other to help others, whether it is fastabiqul khoirot. As well as an invite to the goodness of Habluminannas, namely relationships with fellow humans, can be through gymnastics, not only about religion but also benefits in life. This is what will lead to persuasion to realize true Islam. This was done for members of the community in Ngampilan". (Hj. Siti Bariah, Chairperson of the PCA Ngampilan Yogyakarta Interview, April 20, 2020).

Based on the explanation, it can be seen that the organizational communication carried out by PCA Ngampilan is about Islam and provides grounded activities and communication so that the general public accepts it by entering into social activities. These values are included in persuasive communication that is concerned with the value of Habluminannas emphasized by PCA Ngampilan. Attitude is our tendency towards something to persuasion. Attitude is our liking or disliking something (Maulana \& Gumelar, 2013).

A similar sentiment was also conveyed by PCA Ngampilan related to organizational communication conducted by PCA Ngampilan as follows:

"Asyiyah establishes communication in the community not only through religious activities of a religious nature, such as routine recitations but also through social activities. Also, for example, there are joint gymnastics, PAUD activities that involve the community outside the Asisyiyah organization" (Interview, Feni, Deputy Chairperson of PCA Ngampilan Yogyakarta, Interview April 23, 2020).

Based on the presentation delivered by Feni as the chairman of PCA Ngampilan, it can be seen that communication activities are not only informative. Communication is a means of $d a$ 'wah. A preacher conveys religious messages using verbal and non-verbal symbols. These two types of symbols are the most widely used by da'wah communicators. Verbal symbols include speech and writing that are commonly understood, while nonverbal symbols - in the world of $d a$ 'wah - refer to movements, facial expressions, clothing, actions or behavior, and environmental situations, something that has meaning other than linguistic mechanisms (Ma'arif, 2010).

PCA Ngampilan is like an organization engaged in the Islamic field, so it is important to carry out the role of communication in accordance with the verses of the Al-Qur'an including Qaulan Balighban (delivering fluently), Qaulan Layyinan (communicating gently), Qaulan Sadidan (communicating correctly, accurately, and honest), Qaulan Masyuran (easy to understand), Qaulan Kariman (communicating with noble meaning)(Atabik, 2014)

In realizing the true Islamic society, especially in the community, the organizational communication of the PCA Ngampilan is carried out through various social, educational, and religious activities. The following various activities carried out are shown in Table 9.

Table 9. The Activities of the Aisiyah Branch Chief in Realizing the True Islamic Society

\begin{tabular}{ll}
\hline \multicolumn{1}{c}{ Activities } & \multicolumn{1}{c}{ Notes } \\
\hline $\begin{array}{l}\text { General Recitation: } \\
\text { Once a week at each sub-branch and once a month in each } \\
\text { branch }\end{array}$ & Intended by the general public \\
\hline Charitable business of TK / KB / TPA & Intended by the general public \\
\hline
\end{tabular}




\begin{tabular}{ll}
\hline Giving compensation to orphans, widows, the needy & Intended by the general public \\
\hline Holding healthy exercise every three months & Intended by the general public \\
\hline
\end{tabular}

Based on the data of the table above, it can be seen that the ability of PCA to communicate with the general public through various activities is not only in religious activities but also in social, educational, and health. This was also said by the citizens of Ngampilan as follow:

"In the past, I did not know what Aisyiyah was, but after I joined the recitation every Thursday evening and left my child at the TPA. I am a member of Aisyiyah, and since joining Aisyiyah, I have become more diligent in worshiping at the mosque and leave activity 100 commemorations if there is a family member who dies and the ngapem ritual in the month of ruwah because in my recitation follow that the ngapem ritual activity has no guidance in the Al-Quran and Hadith." (Sulami, Yogyakarta People's Community, Interview March 23, 2020).

PCA Displays conduct external organizational communication, which is informative and persuasive communication packaged in the form of general teaching activities performed routinely in the community to bring a sense of involvement in the community. Downward organizational communication of Aisyiyah Branch Chairman (PCA) Ngampilan is directed to all members of the to perform five main things, ranging from information on how to do the work associated with the task of realizing the true Islamic community, the rationale for doing the job up to a sense of belonging towards Aisyiyah.

These social, educational, and health activities effectively educate and persuade the community. The implementation of activities carried out by PCA Ngampilan is general. It is intended by the community who are not only Muslims, for example, healthy exercise activities and daycare activities (TPA). This is a propaganda cult in nature that can empower the people of Ngampilan. Thus, this organizational communication can empower the community, especially in the social, educational, health aspects, and is also able to embed Islamic values in accordance with the Qur'an and Hadith so as to be able to realize the true Islamic community. So, in this case, the author feels that the role of PCA Ngampilan in community development and Islamic values is a lesson for the community so that they can independently make efforts to improve their quality of life both regarding their welfare and safety in the world and their welfare and safety in the hereafter (Matthoriq, 2014).

Looking at the results of quantitative research data, it can be analyzed with qualitative that the influence of organizational communication has become an important point in Aisyiyah's organization. Internal and external organizational relationships are essential to support and maintain harmonious relationships between members. This situation is in accordance with some previous studies, such as those written by (Osborne 2018) in the study of public service-dominant logic to public service logic. The results of this study state that the relationship of source integration and value propositions becomes an important point to be explored more as it supports public services capable organizations of co-production and value co-creation.

Aisyiyah PCA organization Aisiyah Ngampil Yogyakarta certainly implements a strategy to realize true Islam. In realizing this, strategic planning is internal and external organizational relationships are supporting factors in this regard. This is similar to Elbannna (2016) that strategic planning with the relationship of each organizational line will lead to the successful implementation of the organizational strategy. Especially the 
public manager's collaboration factor, in terms of strategic planning practice, is important for the organization. This shows that the relationship between each relationship in the organization is important for the successful implementation of their strategy.

Moreover, the results of research written by Pestoff (2019) in his book entitled Co-Production and Public Service Management (Citizenship, Governance and Public Service Management) reinforce the results of this study that the relationship between each management organization continues to be essential to the efficient provision of public services (Pestoff, 2019). In reality, these trends have not so much replaced each other as elided or co-existed together-the public policy process has not gone away as a legitimate topic of study, intra-organizational management continues to be essential to the efficient provision of public services, whilst the governance of inter-organizational and inter-sectoral relationships is now essential to the effective provision of these services (Pestoff, 2019).

\section{Conclusion}

From the results and discussion in the previous chapter, it can be concluded that Aisyiyah (PCA) Ngampilan Branch Chief, in realizing the true Islamic society, regularly conducts organizational communication and optimizes downward and upward communication as well as horizontal and vertical communication. Efforts were done routinely by doing regular meetings to exchange information, coordination, and control. It also optimizes informal communication to balance informal communication through Whatsapp Group chat. The organizational communication function in the PCA is to convey information, have a commitment, and encourage the good, especially to uphold Islamic values in accordance with the guidance of the Al-Qur'an and Al-Hadith.

The results of the quantitative data test show that in hypothesis 1, downward communication, the value of $\mathrm{P}$ Values hypothesis 1 that is equal to 0.027 , where PValues hypothesis 1 is smaller than 0.05 , hypothesis 2 have a $T$ value of 2,321 statistics In Hypothesis 3, the T Statistic standard value of 1.96. In addition, the P-value of Hypothesis 3 is 0.007 where the P-value of Hypothesis 3 is smaller than 0.05, hypothesis 4 to find out interline communication, the result is P-value for Hypothesis 4 is 0.013 , and hypothesis 5 is equal to 0.000 where the $\mathrm{P}$ Values value of hypothesis 5 is smaller than 0. 05. All of these show that Downward, Upward, Horizontal, Interline Communication has a positive and significant influence on Organizational Communication realize the true Islamic society.

In realizing a true Islamic society, the communication of the PCA Ngampilan organization is not only related to Habluminnallah, such as reminding each other and always inviting the right prayer, and not doing activities that are not in accordance with the guidance of the Al-Qur'an and Al-Hadith but also persuasive messages that are related with Hablumminannas (interpersonal communication). The communication invites each other to help others (fastabiqul khoirot: compete in good deed), so that the Aisyiyah Organization is more grounded and easily accepted in the general public, not as an Islamic women's but as a social organization. This research shows that organizational communication is an important point in Aisyiyah's organization. Internal and external organizational relationships are important for supporting and maintaining harmonious relationships between members and realizing the true Islamic society. 


\section{Acknowledgements}

Thanks to the Muhammadiyah University of Yogyakarta for supporting this research. Also, thanks to Mrs. Hj. Siti Bariah as PCA leader Aisyiyah Ngampilan Yogyakarta who is willing to be our resource.

\section{References}

Al Rosyid, M.H. (2019). Organizational Communication Darussalam Gontor Modern Islamic Institution Campus in Building the Loyalty of Mahasiswa Guru. Ponorogo, University of Darussalam Gontor.

Anshari, H., Masjaya, H., \& Amin, H. J. (2014). Pengaruh Komunikasi Organisasi dan Budaya Organisasi Terhadap Kinerja Pegawai Bagian Sosial Sekretariat Daerah Kabupaten Kutai Timur. Jurnal Administrative Reform, 2(3), 397-409. https://journal.unbara.ac.id/index.php/fe/article/view/621

Atabik, A. (2014). KONSEP KOMUNIKASI DAKWAH PERSUASIF DALAM PERSPEKTIF AL-QUR'AN. AT-TABSYIR, Jurnal Komunikasi Penyiaran Islam, 2(2), 117-136.

Badri, F. (2018). A genuine Islamic conceptualization of religious freedom. Muslim World Journal of Human Rights, 15(1), 1-27. https://doi.org/10.1515/mwjhr2018-0020

Creswell, J. W. (2010). Research Design: Pendekatan Kualitatif, Kuantitatif, dan Mixed. Pustaka Pelajar.

Effendy, O. J. (2013). Ilmu Komunikasi Teori dan Praktek. Remaja Rosdakarya.

Elbanna, S., Andrews, R., \& Pollanen, R. (2016). Strategic Planning and Implementation Success in Public Service Organizations: Evidence from Canada. Public Management Review, 18(7), 1017-1042. https://doi.org/10.1080/14719037.2015.1051576

Evelina, L. W., \& Angeline, M. (2014). Komunikasi Vertikal dan Horizontal dalam Membentuk Gaya Kepemimpinan Berbasis Kearifan Lokal: Studi pada Binus University. Humaniora, 5(1), 445. https://doi.org/10.21512/humaniora.v5i1.3044

Ghozali, I. (2006). Aplikasi Analisis Multivariate dengan Program SPSS. Badan Penerbit Universitas Diponegoro.

Haryono, S. (2017). Metode SEM Untuk Penelitian Manajemen Dengan AMOS LISREL $P L S$. Luxima Metro Media.

Hermana, D., Barlian, U. C., Organisasi, K., Pendahuluan, A., \& Behavior, O. (2004). Komunikasi Dalam Organisasi. Jurnal Administrasi Pendidikan UPI, 2(2).

Jelahut, F. E., Karlinah, S., \& Novianti, E. (2021, July). Communication Style Organizasaun Lospalos Uan Ukani Members Student in Bandung. Jurnal ASPIKOM, 6(2), 402-412.

Johanna, P. (2013). Hambatan Downward Communication Antara Pimpinan Dan Karyawan PT. Hambatan Downward Communication Antara Pimpinan Dan Karyawan, 26-26. http://publication.petra.ac.id/index.php/ilmukomunikasi/article/viewFile/890/790

Jung, E. (2014). Islamic_Organizations_and_Electoral_Poli (1).pdf. South East Asia Research, 22(1), 73-86

Krafess, Jamal. (2005). The Influence of The Muslim Religion in Humanitarian Aid. International Reviewf of The Red Cross, 87(858),327-342.

Ma'arif, B. S. (2010). Komunikasi Dakwah: Paradigma Untuk Aksi. Simbiosa Rekatama Media. 
Mahmudah, D. (2015). Komunikasi, Gaya Kepemimpinan, Dan Motivasi Dalam Organisasi. Jurnal Studi Komunikasi Dan Media, 19(2), 285. https://doi.org/10.31445/jskm.2015.190210

Markgraf, P. R. (2003). A Study Internal Communication in The Royal Canadian Mounted Police of British Columbia. Royal Roads University.

Markus, S. (2019). Pengaruh komunikasi dari bawahan kepada atasan (upward communication) terhadap motivasi kerja bawahan di Perusahaan Rokok "369". International Conference on Family Business and Entrepreneurship (p. 9). Jakarta: Precident University.

Matthoriq, S. R. (2014). AKTUALISASI NILAI ISLAM DALAM PEMBERDAYAAN MASYARAKAT PESISIR (Studi pada Masyarakat Bajulmati, Gajahrejo, Kecamatan Gedangan, Kabupaten Malang). Jurnal Administrasi Publik (JAP), 2(3), 426-432.

Maulana, H., \& Gumelar, G. (2013). Psikologis Komunikasi dan Persuasi. Akademia Permata.

Muhammad, A. (2017). Organizational Communication. Bumi Pustaka.

Nathania. (2014). Hubungan Aliran Komunikasi Organisasi Dengan Kinerja Karyawan PT.Sarana Lubitama Semesta., Jurnal E-Komunikasi, 2(3).

Nurdin, A. (2020). Kompetensi Komunikasi Wanita Dalam Organisasi Keagamaan Muslimat Dan 'Aisyiyah Di Surabaya. Jurnal Riset Komunikasi, 3(1), 34-50. https://doi.org/10.24329/jurkom.v3i1.111

Osborne, S. P. (2018). From public service-dominant logic to public service logic: are public service organizations capable of co-production and value co-creation? Public Management Review, 20(2), 225-231. https://doi.org/10.1080/14719037.2017.1350461

Osborne, S. P., Radnor, Z., \& Nasi, G. (2013). A New Theory for Public Service Management? Toward a (Public) Service-Dominant Approach. The American Review of Public Administration, 43(2), 135-158. https://doi.org/10.1177/0275074012466935

Pace, R. W., \& Faules, D. F. (2005). Komunikasi Organisasi. Strategi Meningkatkan Kinerja Perusahaan. Alih bahasa: Deddy Mulyana. Remaja Rosdakarya.

Pace, R. W., \& Faules, D. F. (2015). Organizational Communication: Strategies to Improve Company Performance. Remaja Rosdakarya.

Pace, R. Wayne, \& Faules, D. F. (2006). Komunikasi Organisasi, Strategi Meningkatkan Kinerja Perusahaan. Cetakan Ke-6. PT Remaja Rosda Karya.

Pestoff, V. (2019). Co-Production and Public Service Management. Routledge.

Rubtcova, Mariia and Pavenkov, Oleg and Pavenkov, Vladimir. (2017). Religious Communication as the Mean of Spiritual and Moral Value's Translation: Sociological View. Prepared for the Perspectives in Humanities and Social Sciences: Hinting at Interdisciplinarity, 4th Edition: Revolutions, the Archeology of Change Conference (PHSS 2017), Iasi, Romania, 26th to 27th May 2017, Available at SSRN: https://ssrn.com/abstract=2972760

Sugiyono. (2011). Metode Penelitian Kombinasi (Mixed Methods). Alfabeta.

Sugiyono. (2013). Metode Penelitian Pendidikan Pendekatan Kuantitatif, Kualitatif, dan $R \& D$. Alfabeta.

Sukatno, S. T., Huseini, M., Syafganti, I., \& Irwansyah, I. (2018). Komunikasi Internal

Swandhana, H. (2017). Peranan Komunikasi Horizontal Dalam Peningkatan Kinerja Pada Prime Sauce. PERFORMA: Jurnal Manajemen Dan Start-Up Bisnis, 2(2), 
$228-234$.

Tariszka, E. (2002). Organizational Internal Communication as A Means of Improving Efficiency. European Scientific Journal, 8(15), 86-96.

Taurisa, C. M., \& Ratnawati, I. (2012). Analisis Pengaruh Budaya Organisasi dan

Kepuasan Kerja terhadap Komitmen Organisasional dalam meningkatkan Kinerja Karyawan. Jurnal Bisnis Dan Ekonomi (JBE), 19(2), 170-187.

Vito, D. (2011). Human Communication. Pearson Educated Limited. 